\begin{tabular}{|l|l|l|l|l|l|}
\hline J. Tek. Ling & Vol.11 & No.1 & Hal. 127 - 138 & Jakarta, Januari 2010 & ISSN 1441-318X \\
\hline
\end{tabular}

\title{
PENGARUH PEMANFAATAN LIMBAH KULIT SINGKONG DALAM PEMBUATAN PELET RANSUM UNGGAS
}

\author{
Sindu Akhadiarto \\ Peneliti di Pusat Teknologi Produksi Pertanian \\ Badan Pengkajian dan Penerapan Teknologi
}

\begin{abstract}
Cassava peels is one of agriculture waste having potency as feed for poultry. Cassava peels represent waste product from cassava industry with amount 1,998 million ton in the year 2006 in Indonesia (10 percentage of corm of yielded cassava). The weakness of cassava peels are low crude protein content, less palatable for ruminant and have voluminous characteristic. One of the effort to increase usefulness of cassava peels is by using cassava peels as fibre source in pellet complete ration for poultry. The aim of this research was to know best level from utilization of cassava peels as physic quality in poultry complete ration. This study used Completely Randomized Design that consists of three treatments and three replications. The treatments were: 1$)$. Control feeds $+0 \%$ cassava peels (R1), 2). Control feeds $+30 \%$ dry matter cassava peels (R2), 3). Control feeds $+30 \%$ boiling matter cassava peels (R3). Data was analysed with ANOVA and continued with Duncan Test. The result indicated that effect of water content pellet ration with moisture tool is higher than using infrared tool. Pellet rations with dry matter and boiling matter control treatment before saving have physic qualities that still meet the quality standar of poultry ration. Eventhough, on treatment after saving, the physic qualities decrease and relatively less meet the quality standar of poultry ration.
\end{abstract}

Key word: waste, cassava peels, poultry ration, pellet complete.

\section{PENDAHULUAN}

\subsection{Latar Belakang}

Masalah utama dalam meningkatkan produktivitas ternak adalah ransum, karena biaya ransum dapat mencapai $70 \%$ dari seluruh biaya produksi. Penyediaan ransum yang bermutu tinggi merupakan faktor penting yang harus tetap di jaga, baik dari segi nutrisi maupun bentuk fisik. Namun mahalnya harga bahan baku pakan yang sebagian masih impor, perlu dicari alternatife penggantinya. Oleh karena itu pemanfaatan limbah tanaman pangan dan industri pangan mulai dilirik sebagai salah satu solusi untuk mengatasi masalah penyediaan pakan. Selain itu juga sebagai salah upaya untuk mengurangi pencemaran lingkungan yang diakibatkannya. Limbah tanaman pangan dan industri yang dapat dimanfaatkan salah satunya adalah kulit singkong.

Kandungan karbohidrat kulit singkong relative tinggi dan dapat digunakan sebagai sumber energi bagi ternak. Kulit singkong dapat dengan mudah dipisahkan dari umbinya dengan ketebalan 2-3 mm. Persentase kulit singkong yang dihasilkan berkisar antara 8-25 \% dari berat umbi yang dikupas, dengan kandungan karbohidrat sekitar $50 \%$ dari kandungan karbohidrat bagian umbinya. Kulit singkong terbagi atas lapisan paling luar epidermis yang berwarna coklat dan tipis serta lapisan dalam dermis yang 
agak tebal. Potensi limbah kulit singkong di Indonesia masih berlimpah. Data Statistik Pertanian ${ }^{4)}$, menunjukkan bahwa produksi singkong di Indonesia pada 2006 sebesar 19,986 juta ton dengan konversi limbah kulit singkong sebesar 1,998 juta ton (konversi $10 \%$ kulit singkong dari singkongnya). Ketersediaannya dapat dimanfaatkan secara optimal dan berkesinambungan melalui proses penyimpanan. Kualitas nutrisi kulit singkong sebagai pakan dapat dilihat pada Tabel 1 dibawah.

Dari segi nutrisi kulit bagian dalam singkong adalah salah satu limbah pertanian yang dapat dimanfaatkan sebagai bahan pakan alternatif dan dapat diperoleh dari limbah industri tapioca. Masalah yang dihadapi sebagai ransum ternak adalah kandungan nutrisinya yang rendah dan adanya kandungan zat anti nutrisi berupa asam sianida (HCN). Oleh karena itu pemberian kulit bagian dalam singkong sebagai ransum ternak masih sangat terbatas. HCN pada tanaman terdapat dalam bentuk glukosida sianogenik ${ }^{10}$. Linamarin adalah glukosa sianogenik yang tinggi akan kandungan $\mathrm{HCN}$ selama proses hidrolisis pada tanaman ${ }^{18)}$. Kandungan glukosida sianogenik yang normal terdapat pada singkong adalah $15-400$ ppm HCN per kg berat segar²).

Singkong mempunyai enzim linamarase, dimana fungsi enzim ini mempunyai kemampuan melepaskan glukosida sehingga $\mathrm{HCN}$-nya dapat terlepas. Glukosida sianogenik terdiri atas linamarin dan lotaostralin yang jumlah masing-masimg $93 \%$ dan $7 \%$ dari jumlah total glukosida sianogenik dalam tanaman ${ }^{24)}$. Singkong harus diproses secara hati-hati sebab singkong mengandung glusida linamarin yang dengan enzim dapat dipecah menjadi $\mathrm{HCN}^{9}$. Dinyatakan ${ }^{15)}$, bahwa pengolahan dengan cara perendaman, pencucian dan pengeringan dapat menurunkan kadar $\mathrm{HCN}$. Dinyatakan pula ${ }^{26)}$, bahwa racun singkong dapat dikurangi dengan cara diiris, direndam dan dicuci dengan air mengalir. Hilangnya $\mathrm{HCN}$ dari singkong tergantung pada beberapa faktor seperti ukuran potongan, kelembaban, suhu udara, dan angin yang mempengaruhi waktu pengeringan.

Tabel 1. Komposisi Kimia Kulit bagian Dalam Singkong (\% Bahan Kering).

\begin{tabular}{|l|c|c|c|}
\hline Bahan & Devendra (1977) & Adegbola (1986) & Baah (1999) \\
\hline Bahan kering & - & 13,5 & - \\
\hline Protein Kasar & 4,8 & 6,5 & - \\
\hline Serat kasar & 21,1 & 10,0 & - \\
\hline Lemak kasar & 1,2 & 1,0 & - \\
\hline BETN & 68,6 & 62,5 & - \\
\hline Abu & 4,2 & 6,5 & - \\
\hline Bahan organik & - & - & 91,1 \\
\hline NDF & - & - & 57,4 \\
\hline ADF & - & - & 28,4 \\
\hline
\end{tabular}

Sumber : Devendra, C.,(1977), Adegbola (1986) dan Baah J. et.al (1999). 
Sedangkan dari segi bentuk fisik kebanyakan ransum unggas di banyak negara di produksi dalam bentuk butiran dan pellet. Keuntungan memproses pellet adalah mengurangi pengambilan ransum secara selektif oleh unggas, meningkatkan ketersediaan nutrisi, menurunkan energi yang dibutuhkan sewaktu mengkonsumsi ransum, mengurangi kandungan bakteri pathogen, meningkatkan kepadatan ransum sehingga dapat mengurangi biaya penggunaan truk, mengurangi penyusutan ransum karena debu dan memperbaiki penanganan ransum pada menggunaan alat makan otomatis. Semua keuntungan ini akan dapat mengurangi biaya produksi ${ }^{5}$.

Salah satu cara untuk memperbaiki kualitas suatu bahan pakan ternak adalah merubah ukuran partikel bahan tersebut dengan cara memotong, menggiling dan memadatkannya. Kombinasi ketiga cara tersebut membentuk produk yang disebut pellet $^{21}$. Pellet dikenal sebagai bentuk massa dari bahan pakan atau ransum yang dibentuk dengan cara menekan dan memadatkan melalui lubang cetakan secara mekanis ${ }^{11)}$. Bentuk ransum pellet adalah bentuk ekonomis yang umumnya dibuat pabrik untuk ransum ternak unggas usia dewasa. Keuntungan pemakaian jenis ransum pellet ini adalah meningkatkan konsumsi ransum dan meningkatkan kadar energi metabolis ransum seperti komposisi ransum yang mengandung energi metabolis rendah dan ransum yang memiliki serat kasar tinggi, disamping mengurangi jumlah ransum yang terbuang, juga tidak menghasilkan debu seperti pada pakan mash.

Pemakaian ransum bentuk pellet juga akan memperpanjang lama penyimpanan dan menjamin keseimbangan zat- zat nutrisi ransum yang terkandung dan komposisi ransum ${ }^{16)}$. Kualitas pellet yang baik dapat dilihat dari kekerasan, sedikit jumlah pellet yang hancur dan kemampuan pelet untuk tetap mempertahankan bentuknya yang utuh baik pada saat pengangkutan maupun pemberian ransum ${ }^{20)}$.
Ransum berbentuk pellet banyak diproduksi pada industri pakan, tetapi terdapat kendala dalam penggunaan ransum yaitu terjadi kerusakan bentuk fisik atau hancur selama proses pembuatan dan pengangkutan lebih besar dibanding ransum bentuk tepung (mash). Kerusakan bentuk fisik akan mempengaruhi daya beli konsumen yang cenderung melihat kualitas ransum dari segi fisik. Kualitas fisik ransum penting diketahui dan berguna dalam proses pengeringan, penyimpanan, pemindahan massa bahan dan pengolahan. Dalam usaha pengembangan teknologi pakan sifat fisik ransum memegang peranan yang sangat penting terutama ransum bentuk pellet, oleh karena itu pengetahuan tentang kualitas fisik ransum perlu untuk dipelajari.

\subsection{Tujuan}

Penelitian ini bertujuan untuk mengetahui kualitas fisik kulit bagian dalam singkong dalam pembuatan ransum unggas bentuk pellet.

\section{METODOLOGI}

Penelitian dilaksanakan mulai bulan Desember 2007 sampai Januari 2008. bertempat di Laboratorium Industri Makanan Ternak, Fakultas Peternakan, Institut Pertanian Bogor.

\subsection{Bahan dan Alat}

Bahan penelitian yang digunakan dalam pembuatan ransum broiler adalah dedak padi, jagung, bungkil kedelei, tepung ikan, bungkil kelapa, minyak sayur, top mix dan kulit bagian dalam singkong. Sedangkan alat-alat yang digunakan dalam penelitian ini adalah : alat proses pembuatan pellet terdiri dari mesin pencetak pellet (farm pelleter machine) dan alat untuk analisa fisik terdiri dari timbangan, rica moisture, infra red, gelas ukur $100 \mathrm{ml}$, pengaduk, corong, kertas, Aw meter, sendok, plastik, alat durabiliti, jangka sorong dan mesin jahit. 


\subsection{Metode}

Pembuatan tepung kulit bagian dalam singkong dilakukan dengan cara sebagai berikut, yaitu pertama dengan membersihkan kulit bagian dalam singkong. Untuk yang perlakuan kering langsung dijemur dengan sinar matahari selama 7 hari sampai kering sehingga siap untuk dijadikan tepung. sedangkan untuk yang kukus, kulit bagian dalam singkong terelebih dahulu dipanaskan selama 30 menit kemudian untuk proses selanjutnya sama dengan perlakuakn kering.

Jenis ransum yang digunakan pada praktikum ini adalah ransum broiler starter. Formulasi ransum berdasarkan NRC ${ }^{19}$ ) dengan menggunakan protein kasar 21 dan energi metabolis $3000 \mathrm{kkal} / \mathrm{kg}$ ransum. Formulasi ransum dibuat metode trial and error (Tabel 2 danTabel 3). Ransum terdiri dari R1 = Ransum Kontrol $+0 \%$ kulit bagian dalam singkong, $\mathrm{R} 2$ = Ransum Kontrol + $30 \%$ kulit bagian dalam singkong kering, dan $\mathrm{R} 3=$ Ransum Kontrol $+30 \%$ kulit bagian dalam singkong kukus.

Tabel 2. Formulasi Ransum Kontrol (Basal) Broiler Starter.

\begin{tabular}{|l|l|}
\hline Bahan & $\begin{array}{l}\text { Ransum Kontrol } \\
(\%)\end{array}$ \\
\hline Dedak & 8,5 \\
\hline Jagung & 54 \\
\hline Bungkil kedelei & 15,50 \\
\hline Tepung ikan & 13,4 \\
\hline Bungkilkelapa & 6,5 \\
\hline Minyak sayur & 2 \\
\hline Top mix & 0,1 \\
\hline Total & 100 \\
\hline
\end{tabular}

Tabel 3 Kandungan Zat Makanan per 100\% Bahan Berdasarkan Perhitungan.

\begin{tabular}{|l|l|}
\hline Zat Makanan & Jumlah \\
\hline Energi metabolis (kkal/kg) & $3.001,4$ \\
\hline Protein kasar (\%) & 21,2075 \\
\hline Lemak kasar (\%) & 11,126 \\
\hline Serat kasar (\%) & 3,564 \\
\hline Ca (\%) & 1,249 \\
\hline
\end{tabular}

Sedangkan teknik pembuatan pellet adalah sebagai berikut. Bahan-bahan yang telah digiling dipersiapkan sesuai dengan formulasi. Formulasi ransum dibuat sesuai dengan tingkat penggunaan kulit bagian dalam singkong yang dikukus dan dikeringkan sebesar $30 \%$ dan dicampur secara merata. Campuran bahan dimasukkan kedalam lubang pemasukan mesin pellet lalu dicetak, ditekan oleh roll dan setelah keluar dari lubang roll dipotong oleh pisau pemotong dan keluar dalam bentuk pellet. Selanjutnya pellet digiling dengan cara diangin-anginkan.

\section{Peubah yang Diamati \\ Kerapatan Tumbukan ${ }^{13)}$.}

Kerapatan tumbukan dihitung dengan mencurahkan bahan dengan bobot tertentu ke dalam gelas ukur $(100 \mathrm{ml})$. Metode pemasukan bahan ke dalam gelas ukur sama setiap pengamatan, baik cara maupun ketinggian pencurahan. Pencurahan ransum dibantu corong plastik dan sendok the guna memimiumkan penyusutan volume curah akibat pengaruh daya berat ransum itu sendiri saat dicurahkan dan terjadi guncangan pada ukur perlu dihindari kerapatan tumbukan dihitung dengan rumus :

$$
\mathrm{KT}=\quad \text { berat bahan (gram) }
$$




\section{Aktivitas Air.}

Sebelum Aw meter digunakan perlu dilakukan kalibrasi terlebih dahulu dengan larutan garam Barium Klorida $\left(\mathrm{BaCl}_{2}\right)$, kemudin dibiarkan selama 3 menit setelah jarum Awmeter ditera sampai menunjukkan angka 0,9 karena larutan $\mathrm{BaCl}_{2}$ mempunyai kelembaban garam jenuh sebesar $90 \%{ }^{23 \text {. }}$. Pengukuran aktivitas air dilakukan dengan cara memasukkan ransum kedalam Awmeter sampai menutupi permukaan kemudian ditutup dan dibiarkan selama 3 menit, setelah itu pembacaan segera dilakukan.

\section{Sudut Tumbukan ${ }^{14) .}$}

Pengukuran sudut tumbukan dilakukan seperti gambar 4, dengan cara menjatuhkan atau mencurahkan bahan pada ketinggiaan $15 \mathrm{~cm}$. Diameter tumbukan bahan maksimum setengah kali tinggi jatuhnnya bahan. Sebagai alas bidang datar digunakan karton manila berwarna putih. Ketinggian tumbukan bahan harus selalu berada dibawah corong plastik Pengukuran diameter dilakukan pada sisi yang sama pada semua pengamatan dan bantuan mistar dan segitiga siku-siku. Sudut tumbukan bahan dinyatakan dengan satuan derajat (o) dan dapat di tentukan dengan mengukur diameter dasar (d) dan tinggi tumbukan $(\mathrm{t})$ sedangkan $(\mathrm{n})$ adalah ketinggian tertentu untuk menjatuhkan bahan. Besarnya sudut tumbukan dapat dihitung dengan rumus : $\&=\operatorname{Cotg}(2 t / d)$

\section{Durabiliti.}

Diukur dengan menggunakan Pellet Durability Tester dengan memasukkan pellet sebesar $500 \mathrm{gr}$ kedalam kotak uji,lalu kotak ditutup dan mesin dinyalakan selama 10 menit sehingga kotak menjadi berputar dengan sudut putaran sebesar $360 \mathrm{o}$. pellet lalau dikeluarkan dari kotak uji dan disaring dengan menggunakan Vibrator Ball Mill selama 10 menit. Kemudian dilakukan penimbangan. Rumusnya:

$$
\begin{aligned}
& \text { Pellet } \\
& \begin{array}{l}
\text { Durability } \\
\text { Index }
\end{array}=\frac{\begin{array}{l}
\text { Berat pellet utuh } \\
\text { setelah diuji }
\end{array}}{\text { berat pellet utuh }} \times 100
\end{aligned}
$$

\section{Rancangan Percobaan}

Rancangan percobaan yang digunakan adalah Rancanagan Acak Lengkap (RAL) dengan tiga perlakuan dan tiga ulangaan. Data yang diperoleh dianalisis dengan menggunakan sidik ragam (Analisis of Variance) dan apabila terdapat perbedaan yang nyata dilakukan uji Duncan.

\section{HASIL DAN PEMBAHASAN}

\subsection{Keadaan Umum Kulit Bagian Dalam Singkong}

Sifat fisik dari kulit bagian dalam singkong yang dibuat dapat diketahui dari pengujian kadar air, aktivitas air, sudut tumbukan, kerapatan dan durabiliti. Peubah yang diamati ini disajikan Tabel 4 .

Tabel 4. Rataan Hasil Pengukuran terhadap Peubah yang Diamati.

\begin{tabular}{|l|l|l|}
\hline Peubah & \multicolumn{2}{|c|}{ Perlakuan } \\
\hline & Kukus & Kering \\
\hline $\begin{array}{l}\text { Kadar air (rica moisture) } \\
(\%)\end{array}$ & 17,8 & 14,8 \\
\hline Kadar air (infra red) (\%) & 15,4 & 13,07 \\
\hline Aktivitas air (Aw) & 0,78 & 0,76 \\
\hline
\end{tabular}

Tabel 4 menunjukkan bahwa kulit bagian dalam singkong yang mendapat perlakuan kering memiliki nilai rataan yang relatif rendah terhadap peubah-peubah yang diamati, dibandingkan dengan kulit bagian singkong yang mendapat perlakuan kukus.

Kadar air kulit bagian dalam singkong yang mendapat perlakuan kering memiliki rataan lebih rendah $(14,8 \%$ dan $13,07 \%)$ dibandingkan dengan rataan kulit bagian dalam ubi yang mendapat perlakuan 
kukus $(17,8 \%$ dan 15,4), hal ini diduga karena terjadi penambahan air pada waktu pengukusan dan pada waktu pembuatan kulit bagian dalam singkong menjadi tepung perlakuan yang dikukus belum begitu kering sehigga rataan kadar airnya menjadi tinggi. Sedangkan kadar air menggunakan rica moisture rataan lebih tinggi dibandingkan dengan menggunakan infra red hal ini mungkin disebabkan karena penggunaaan alat yang kurang tepat sehingga tingkat ketelitiannyapun menjadi rendah, biasanya penggunaan alat rica moisture untuk mengukur kadar air yang berasal dari butiran seperti jagung.

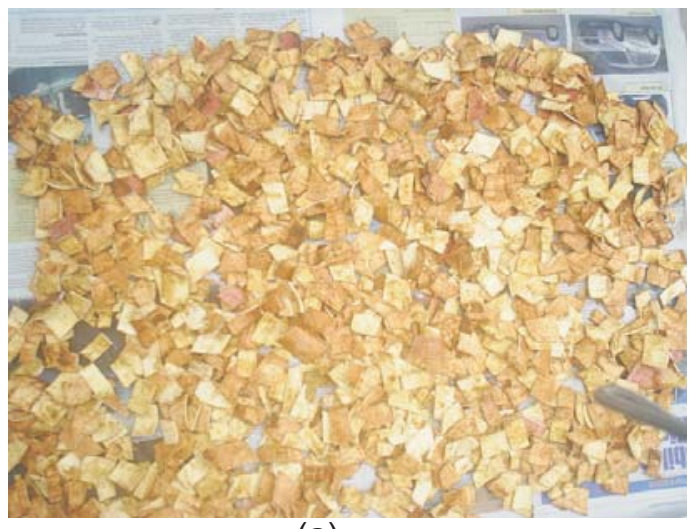

(a)
Rataan aktivitas air kulit bagian dalam singkong yang mendapat perlakuaan kukus lebih tinggi $(0,78)$ dibandingkan dengan yang mendapat perlakuan kering $(0,76)$, akan tetapi rataan ini masih relatif rendah untuk pertumbuhan kapang. Dinyatakan ${ }^{25}$, , bahwa aktivitas air minimum agar dapat tumbuh kapang adalah 0,8 - 0,9.

Bila dilihat secara makroskopis, nampak jelas bahwa kulit bagian dalam singkong yang mendapat perlakuan kering, warnanya lebih ke bentuk asli dibandingkan kulit singkong yang mendapat perlakuan kukus, hal ini diduga karena pada waktu pengukusan kulit bagian singkong mengalami perubahan warna sebagai akibat pemanasan (gambar1) .

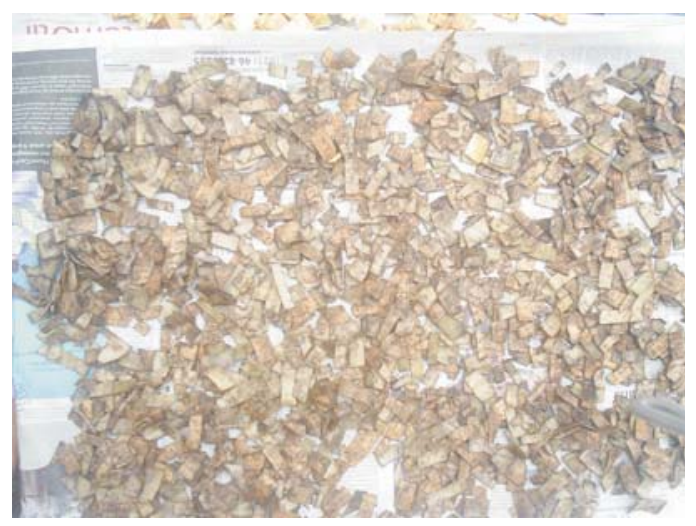

(b)

Gambar 1. Kulit bagian dalam singkong : (a) Kering dan (b) Kukus

\subsection{Keadaan umum Pelet Mengandung Kulit Bagian Dalam Singkong}

Keadaa umum ransum berbentuk pellet yang mengandung kulit bagian dalam singkong diasjikan pada gambar 2 .

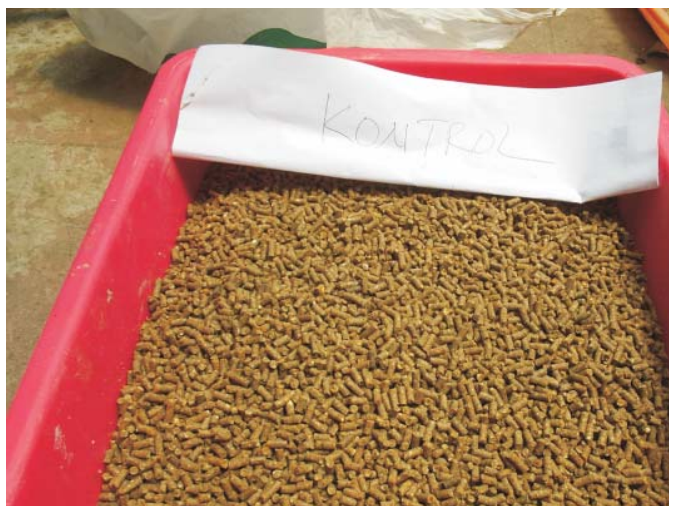

(a) 


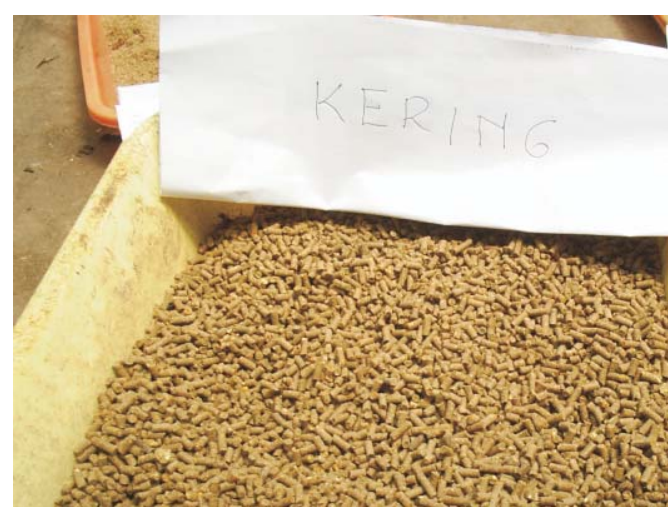

(b)

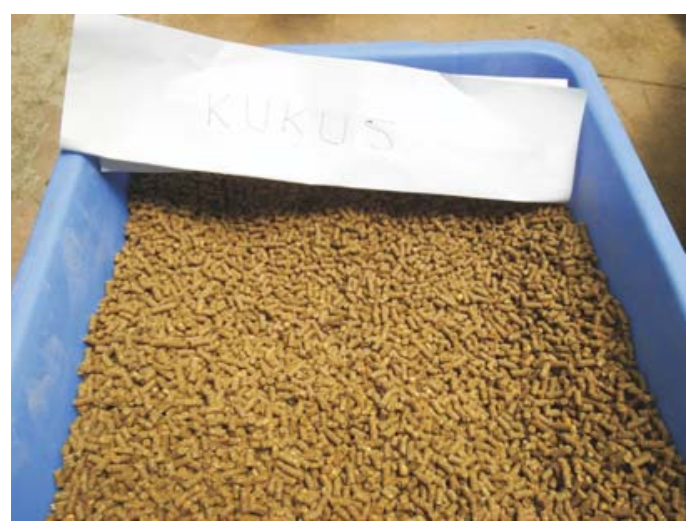

(c)

Gambar 2. Ransum bentuk pellet : (a) tanpa kulit bagian dalam singkong; (b) dengan bagian dalam singkong kering, dan (c) dengan bagian dalam singkong kukus.

Gambar 2 menunjukkan bahwa secara makroskopis ransum pellet mengandung kulit bagian dalam singkong yang dikukus (c) warnanya lebih agak coklat kehitaman dibandingkan ransum kontrol (a) dan ransum pellet yang mengandung kulit bagian dalam singkong yang kering (b). Hal ini disebabkan karena terjadi perubahan warna ransum pellet yang dikukus akibat pemanasan, dimana persentase pemakaian perlakuan ini $30 \%$ dari total jumlah ransum.

\subsection{Kualitas Fisik Ransum Berbentuk Pelet Sebelum Penyimpanan}

Hasil pengukuran kualitas fisik ransum berbentuk pellet mengandung kulit singkong dengan perlakuan kontrol, kering dan kukus sebelum penyimpanan dapat dilihat pada Tabel 5 .

Keterangan : Superskrip yang berbeda pada kolom yang sama menunjukan perbedaan nyata $(P<0,05)$

Tabel 5. Hasil Pengukuran Kualitas Fisik Ransum Berbentuk Pelet sebelum Penyimpanan.

\begin{tabular}{|l|l|l|l|}
\hline Peubah & \multicolumn{3}{|c|}{ Perlakuan } \\
\hline & Kontrol & Kukus & Kering \\
\hline Kadar air rica moisture (\%) & $20,25 a$ & $19,27 a$ & $19,17 a$ \\
\hline Kadar air infra red (\%) & $11,20 a$ & $10,73 a$ & $10,13 a$ \\
\hline Akvititas air (Aw) & $0,78 a$ & $0,78 a$ & $0,77 a$ \\
\hline Kerapatan tumbukan (gr/ml) & $0,67 b$ & $0,61 a$ & $0.63 a$ \\
\hline Sudut Tumbukan (0) & $21,09 a$ & $21,87 a$ & $21,98 a$ \\
\hline Durabiliti $(\%)$ & $93,3 a$ & $97,3 a$ & $96,0 a$ \\
\hline
\end{tabular}




\section{Kadar Air}

Kadar air sangat berpengaruh terhadap kualitas ransum. Pengurangan kadar air bertujuan untuk mengurangi berat ransum sehingga memudahkan dan menghemat pengepakan ${ }^{26)}$. Hasil analisis sidik ragam menunjukkan bahwa perlakuan tidak berbeda nyata $(P<0,05)$ terhadap kadar air, baik yang menggunakan alat rica moisture maupun dengan alat infra red, ini menunjukkan bahwa kadar air antar perlakuan ransum pellet kontrol, kukus dan kering relatif sama (Tabel 5). Terjadi perbedaan yang menyolok nilai rataan kadar air yang menggunakan alat rica moisture dengan alat infra red, dimana nilai rataan kadar air untuk perlakuan kontrol, kukus dan kering menggunaan alat rica moisture lebih tinggi masing masing berturur-turut adalah $20,25 \%, 19,27 \%$ dan $19,17 \%$ dibandingkan dengan menggunakan alat infra red masing masing berturut-turut adalah $11,20 \%, 10,73 \%$ dan $10,13 \%$, perbedaan ini di duga karena pemakaian alat tersebut yang berbeda. Kalau rica moisture dipakai untuk mengukur bahan baku yang berbentuk butiran dan biasa dipakai di lapangan sedangkan infra red biasanya di laboratorium. Selain itu tingkat ketelitian untuk mengukur kadar air menggunaan rica moisture relatif rendah dibandingkan infra red.

\section{Aktivitas Air (Aw)}

Nilai aktivitas air (Aw) dalam ransum akan mempengaruhi daya tahan makanan terhadap serangan mikroba. Hasil analisis sidik ragam menunjukkan bahwa aktivitas air (Aw) tidak berpengaruh nyata $(P<0,05)$ terhadap perlakuaan kontrol, kukus dan kering. Ini menandakan bahwa aktivitas air (Aw) untuk semua perlakuan baik itu kontrol, kukus dan kering memiliki rataan yang relatif sama. Rataan perlakuan kontrol, kukus dan kering masing-masing berturut-turut adalah $0,78,0,78,0,77$, bila dilihat dari rataan ini ransum perlakuan belum memungkinkan tumbuhnya kapang, khamir dan bakteri. Dinyatakan pula ${ }^{8)}$, bahwa nilai aktivitas air minimal (Aw) yang mencemari bahan dapat digolongkan menjadi tiga yaitu kapang dan khamir aktivitas air (Aw) 0.8-0,9, sedangkan bakteri aktivitas air (Aw) 0,9.

\section{Kerapatan Tumbukan}

Kerapatan tumbukan adalah perbandingan antara berat bahan dengan volume ruang yang ditempatinya. Hasil analisis sidik ragam kerapatan tumbukan antar perlakuan berbeda nyata $(P<0,05)$, dengan nilai rataan berkisar antara 0,61 $0,67 \mathrm{gr} / \mathrm{ml}$. Ratan yang tertinggi terdapat ransum pellet yang mendapat perlakuan kontrol yaitu $0,67 \mathrm{gr} / \mathrm{ml}$ dan rataan yang rendah pada ransum kukus yaitu 0,61 ml/ gr. Nilai kerapatan tumbukan akan semakin menurun dengan penambahan kulit bagian dalam singkong baik pada perlakuan kukus maupun yang kering. Hal ini sesuai dengan pendapat ${ }^{12)}$, bahwa nilai kerapatan tumbukan akan semakin meningkat dengan semakin banyak jumlah partikel halus dalam ransum tersebut. Dari hasil praktikum menunjukan bahwa ukuran partikel cenderung semakin besar dengan penambahan kulit bagian dalam singkong dalam ransum pellet sehingga kerapatan tumbukan semakin kecil.

\section{Sudut Tumbukan}

Sudut tumbukan dipengaruhi oleh perbedaan ukuran partikel pellet. Semakin besar ukuran partikel suatu bahan maka sudut yang terbentuk akan semakin kecil. Hasil analisis sidik ragam menunjukkan bahwa sudut tumbukan antar perlakuan tidak berbeda nyata $(P<0,05)$, ini menunjukkan bahwa perlakuan kontrol, kukus dan kering mempunyai nilai rataan yang relatif sama. Pada Tabel terlihat bahwa kisaran rataan sudut tumbukan antara perlakuakn kontrol, kukus dan kering masing masing yaitu 21,09o, 21,870 dan 21,980, bila melihat rataan ini masih dalam kisaran. Hal ini berdasarkan penelitian ${ }^{14)}$, bahwa sudut tumbukan ransum bentuk padat berkisar antara 200 - 500. 


\section{Durabiliti}

Tujuan dari uji durabiliti adalah untuk mengetahui apakah pellet yang dibuat akan tahan terhadap benturan dan gesekan baik pada saat penyimpanan, pengangkutan dan pemberian pakan. Hasil analisis ragam menunjukkan bahwa perlakuan tidak berbeda nyata $(P<0,005)$ terhadap durabiliti, ini menandakan bahwa perlakuan kontrol, kukus dan kering memiliki nilai rataan yang relatif sama. Bila dilihat rataan durabiliti masing -masing perlakuakn kontrol, kukus dan kering adalah berkisar antara 93,3\%, 97,3 dan $96 \%$, maka perlakuan ransum bentuk pellet ini mempunyai nilai durabiliti lebih dari $90 \%$ masih dianggap cukup baik untuk diberikan kepada ternak maupun untuk disimpan atau pengangkutan.

\subsection{Kualitas Fisik Ransum Berbentuk Pelet Setelah Penyimpanan}

Hasil analisis ragam pengukuran kualitas fisik ransum berbentuk pellet setelah penyimpanan disajikan pada Tabel 6 . ransum pada saat disimpan. Hasil analisis ragam menunjakkan bahwa kadar air ransum perlakuan tidak berbeda nyata $(P<0,05)$ dengan menggunakan alat rica moisture sedangakan kadar air yang menggunakan alat infra red berbeda nyata terhadap perlakuan. Dugaan yang sama sebelum penyimpanan kadar air ransum perlakuan yang menggunakan alat rica moisture lebih tinggi dibandingkan dengan menggunakan alat infra red yaitu pemakaian alat tersebut yang berbeda. Kalau rica moisture dipakai untuk mengukur bahan baku yang berbentuk butiran dan biasa dipakai di lapangan sedangkan infra red biasanya di laboratorium. Selain itu tingkat ketelitian untuk mengukur kadar air menggunaan rica moisture relatif rendah dibandingkan infra red. Pada Tabel 6 terlihat kadar air perlakuan ransum pellet setelah penyimpanan dengan penggunaan alat infra red nyata lebih tinggi dibandingkan perlakuan ransum pellet sebelum penyimpanan, hal ini diduga karena adanya pengaruh kelembaban dan suhu ruangan. Bila kelembaban udara ruang

Tabel 6. Hasil Pengukuran Kualitas Fisik Ransum Berbentuk Pelet setelah Penyimpanan.

\begin{tabular}{|l|l|l|l|}
\hline Peubah & \multicolumn{3}{|c|}{ Perlakuan } \\
\hline & Kontrol & Kukus & Kering \\
\hline Kadar air rica moisture (\%) & $25,00 \mathrm{a}$ & $23,87 \mathrm{a}$ & $24,33 \mathrm{a}$ \\
\hline Kadar air infra red (\%) & $17,67 \mathrm{a}$ & $16,27 \mathrm{~b}$ & $15,25 \mathrm{~b}$ \\
\hline Akvititas air (Aw) & $0,83 \mathrm{a}$ & $0,82 \mathrm{~b}$ & $0,81 \mathrm{~b}$ \\
\hline Kerapatan tumbukan (gr/ml) & $0,60 \mathrm{a}$ & $0,62 \mathrm{a}$ & $0.62 \mathrm{a}$ \\
\hline Sudut Tumbukan (o) & $33,78 \mathrm{a}$ & $33,30 \mathrm{a}$ & $32,98 \mathrm{a}$ \\
\hline Durabiliti (\%) & $87,0 \mathrm{a}$ & $89,0 \mathrm{a}$ & $92,0 \mathrm{a}$ \\
\hline
\end{tabular}

Keterangan : Superskrip yang berbeda pada kolom yang sama menunjukan perbedaan nyata $(P<0,05)$

Kadar Air.

Faktor-faktor yang mempengaruhi penyimpanan ransum adalah tipe atau jenis ransum, periode atau lama penyimpanan, metode pemyimpanan selain itu yang tidak kalah pentingnya adalah kandungan air penyimpanan tinggi maka akan terjadi absobrsi uap air dari udara ke ransum sehingga menyebabakan kadar air ransum meningkat, begitu juga sebaliknya ${ }^{27)}$.

Kadar air dengan menggunakan alat infra red perlakuan kontrol lebih tinggi 
dibandingan dengan perlakuan kukus dan kering, hal ini di duga adanya produksi air metobolik hasil proses respirasi lebih banyak dibandingkan air yang hilang pada proses transpirasi, sehingga terjadi akumulasi air diantara sel yang pada akhirnya kadar air meningkat. Secara sederhana proses respirasi dapat digambarkan dengan persamaan sebagai berikut:

$$
\mathrm{C}_{6} \mathrm{H}_{12} \mathrm{O}_{6}+6 \mathrm{O}_{2} \longrightarrow 6 \mathrm{H}_{2} \mathrm{O}+6 \mathrm{CO}_{2}+\text { Energi }
$$

Dari tabel terlihat bahwa pengukuran kadar air perlakuan menunjukkan kisaran $15,25 \%-17,67 \%$. Nilai kadar air ini tidak memenuhi persyaratan mutu ransum Standar Nasional Indonesia bahwa kadar air maksimum untuk ransum unggas $14 \%^{7)}$.

\section{Aktivitas Air (Aw)}

Aktivitas air adalah jumlah air bebas yang dapat digunakan oleh mikroorganisme untuk pertumbuhan. Hasil analisis ragam menunjukan bahwa perlakuan berbeda nyata terhadap aktivitas air $(A w)(P<0,05)$. terlihat pada tabel rataan aktivitas air (Aw) pada perlakuan kontrol lebih tinggi dibandingkan dengan perlakuan kukus dan kering, ini diduga karena terjadinya kenaikan kelembaban dan suhu lingkungan selama penyimpanan, sehingga pada kondisi tersebut menyebabkan terjadi absorpsi uap air dari udara ke bahan, begitu juga sebaliknya air yang terabsorpsi ini akan menempel pada permukaan ransum perlakuan, sehingga semakin banyak lapisan yang terbentuk akan meyebakan besarnya nilai aktivitas air (Aw) dan kadar air. Selain itu juga disebabkan jumlah air bebas yang terdapat pada ransum kontrol lebih banyak selama penyimpanan, yang nantinya digunakan mikroorganisme untuk pertumbuhannya. Rataan aktivitas air (Aw) selama penyimpanan perlakuan kontrol, kukus dan kering masing-masing berturutturut adalah $0,83,0,82,0,81$, bila dilihat dari rataan ini ransum perlakuan menmungkinkan untuk tumbuhnya mikroorganisme seperti kapang, khamir dan bakteri. Dinyatakan pula ${ }^{23)}$, bahwa mikroorganisme mempunyai aktivitas air (Aw) minimum agar dapat tumbuh dengan baik, bakteri Aw; 0,9, khamir 0.80- 0,90 dan kapang 0,80-0,90..

\section{KarapatanTumbukan}

Kerapatan tumbukan penting untuk menghitung volume ruang yang dibutuhkan suatu bahan dengan berat tertentu. Hasil analisis ragam menunjukkan bahwa perlakuan tidak berbeda nyata $(P<0,05)$ terhadap kerapatan tumbukan, ini menandakan bahwa kerapatan tumbukan antar perlakuan kontrol, kukus dan kering mempunyai nilai rataan yang relatif sama. Pada tabel 9 ditunjukkan bahwa rataan kerapatan tumbukan untuk perlakuan kontrol, membutuhkan ruang peyimpanan yang kecil. Menurut hasil penelitian ${ }^{22)}$ bahan dengan kerapatan tumbukan rendah $(450 \mathrm{~kg} /$ $\mathrm{m}^{3}$ ) membutuhkan waktu jatuh dan mengalir lebih lama sehingga dapat ditimbang dengan teliti menggunakan alat penakar otomatis sedangkan kerapatan tumbukan yang tinggi $\left(500 \mathrm{~kg} / \mathrm{m}^{3}\right)$ bersifat sebaliknya.

\section{Sudut Tumbukan}

Sudut tumbukan akan mempengaruhi daya alir suatu bahan terutama akan berpengaruh terhadap kecepatan dan efisiensi proses pengosongan silo secara vertikal pada saat memindahkan bahah menuju unit penimbangan bahan atau pada saat pencampuran bahan dan juga berpengaruh terhadap efisiensi pengangkutan bahan secara mekanik. Rataan sudut tumbukan perlakuan kontrol, kukus dan kering masing- masing adalah $33,78^{\circ}, 33,40^{\circ}$ dan $32,98^{\circ}$. Dinyatakan pula ${ }^{14)}$, bahwa sudut tumbukan bahan yang mempunyai nilai lebih $29^{\circ}$ termasuk bahan yang mudah diangkut dengan alat mekanik sehingga perlakuan ransum ini juga mudah diangkut dengan alat mekanik karena nilai rataannya lebih dari 290. Hasil analisis ragam menunjukan bahwa perlakuan tidak 
berbeda nyata $(P<0,05)$ terhadap sudut tumbukan, hal ini menunjukan bahwa sudut tumbukan antar perlakuan memiliki nilai rataan yang relatif sama.

\section{Durabiliti}

Hasil analisis ragam menunjukkan bahwa perlakuan memberikan pengaruh tidak nyata $(P<0,005)$, ini berarti bahwa perlakuan kontrol, kukus dan kering memiliki nilai rataan yang relatif sama. Bila dibandingkan dengan ransum perlakuan sebelum penyimpanan terlihat bahwa nilai rataannya setelah penyimpanan lebih rendah hal ini diduga karena ransum perlakuan telah mengalami proses penyimpanan yang cukup lama sebelum uji durabiliti dilakukan sehingga menyebabkan terjadi penurunan kualitas ransum pellet. Seharusnya uji durabiliti dilakukan segera setelah ransum pellet dibuat dan didinginkan(17). Jika uji durabiliti tidak segera dilakukan, maka akan menurunkan kualitas dari pellet yang dibuat.

\section{KESIMPULAN}

Kadar air perlakuan ransum bentuk pelet menggunakan alat rica moisture lebih tinggi dibandingkan dengan menggunakan alat infra red

Ransum bentuk pellet perlakuan kontrol, kukus dan kering sebelum penyimpanan pada peubah kadar air, aktivitas air (Aw), kerapatan, sudut tumbukan dan durability kualitas fisiknya masih memenuhi standar mutu ransum unggas. Sedangkan pada perlakuan setelah penyimpanan kualitas fisiknya sudah mengalami penurunan dan relatif kurang memenuhi standar mutu ransum unggas

\section{DAFTAR PUSTAKA}

1. Adegbola AA, Asaolu VO. 1986. Preparation of cassava peels for use in small ruminant production in Western Nigeria. in : toward optimum feeding of agricultural by-products to livestock in Afrika.. Preston. T.R. nuwanyakpa, M.Y. (eds). Pp 109115. proc. of workshop held at the University of Alexandria, Egypt, Oct. 1985. ILCO, Addis Ababa. Ethiopia.

2. Balagopan C, Padmaja G, Mootry SN. 1988. Cassava Food. Feed and Industry. CRC. Press. Inc. Princeton. New Jersey.

3. Baah J, Tait MR, Tuah KA. 1999. The effect of suplementation with ficus leaves on the utilization of cassava peels by sheep. Biores. Tecnol. 67: 47-51.

4. BPS, 2008. Statistik Pertanian 2006. BPS, Jakarta.

5. Dozier. A. W. 2001. Kulaitas Pelet Pakan Unggas Pedaging. Feed International.

6. Devendra C. 1977. Cassava as a Feed Source for Ruminants. In. Nestle B and Graham M (eds). Casssava as Animal Feed. IDRC. Canada. 1-07119.

7. Direktorat Bina Produksi. 1997. Kumpulan SNI Ransum. Direktorat Jenderal Peternakan Departemen Pertanian. Jakarta.

8. Fardiaz S.1992. Mikrobiologi Pengolahan Pangan Lanjut. Departemen Pendidikan dan Kebudayaan. Dirjen Perguruan Tinggi. PAU Pangan dan Gizi. IPB. Bogor.

9. Gohl BO. 1981. Tropical Feed. Feed Information Summaries and Nutritive Values. Food and Agriculture Organization the United Nation. Rome.

10. Hahn SK, Terry ER, Leuschner K, Singh TP. 1977. Cassava Improvements Strategies for Resistance of Major. Economic Disease and Pests in Africa. International Institute of Tropical Agriculture Ibadan. Nigeria. 
11. Hartadi, H.S. dan A.D. Tilman. 1986. Tabel Komposisi Pakan untuk Indonesia. Penerbit Universitas Gadjah Mada. Yogyakarta.

12. Johnson, J.R. 1994. The Realities of Bulk Solid Properties Testing. Bulk Solid Handling 14(1) : $129-132$. USA

13. Khalid. 1999a. Pengaruh kandungan air dan Ukuran Partikel Terhadap sifat Fisik Pakan Lokal : Kerapatan Tumpukan, kerapatan Pemadatan dan berat Jenis. Media peternakan 22(1) : $1-11$.

14. Khalid. 1999b. Pengaruh kandungan air dan ukuran Partikel Terhadap sifat Fisik Pakan Lokal : Sudut Tumbukan, Daya Ambang dan Faktor Higroskopis. Media peternakan 22(1) : 33-43.

15. Muller Z, Chau KC, Nah. 1974. Cassava as subtitution for general in livestock and poultry ration, In : World Animal Review 12:12-14.

16. Murtidjo, B.A.1989. Pedoman Meramu Pakan Unggas. Kanisius. Yogfyakarta.

17. McEllhiney, R.R. 1994. Feed Manufacturing Industry 4th Ed. Americvan Feed Industry Asssosiacitin Inc. Arlington.

18. Natragwu NE, Ademale AF. 1977. Loss of Hydrocyanic Acid and Its Derivatives During Sun Drying of Cassava. Tropicals Root Crops Research Strategies for 1980's. Departements of Biochimestry. University of Ibadan. Nigeria.

19. NRC (National Research Council), 1994. Nutrient Requirements of Poultry. 9 th. Revised Edition. National Academy Press, Washington D.C.

20. Slinger, S.J. 1973. Effect of Pelleting and Crumbling Method on the
Nutritional Value Of Feeed. National Academy of Scences. Washington, D.C.

21. Sundstol, F. 1984. Straward Other Fibrous by Product as Feed. Elsevier Press. Amsterdam.

22. Suadnyana, I.W., 1998. Pengaruh Kandungan Air dan Ukuran Partikel terhadap Perubahan Sifat Fisik Pakan Lokal Sumber Protein. Skripsi.Fakultas Peternakan. Institut Pertanian Bogor. Bogor.

23. Syarief, R. dan H. Halid. 1993. Teknologi Penyimapanan Pangan. Arcan. Jakarta

24. Togatorop MH. 1988. Pengaruh penggunaan tapioka dalam ransum yang mengandung berbagai tingkat energi dan protein terhadap performans ayam pedaging yang di pelihara dalam kandang berlantai litter dan kawat [Thesis]. Bogor: Intitut Pertanian Bogor. Program Pascasarjana Program Studi IImu Ternak.

25. Winarno FG. 1994. Kimia Pangan dan Gizi. PT. Gramedia Pustaka Utama. Jakarta

26. Winarno, F.G., S. Fardiaz dan D. Fardiaz. 1980. Pengantar Teknologi Pangan. Pt. Gramedia. Jakarta.

27. Yuliastanti, A. 2001. Uji Sifat Fisik Ransum Ayam Broiler Starter Bentuk Mash, Pelet dan Crumble selama Penyimpanan Enam Minggu. Skripsi. Fakultas Peternakan. Institut Pertanian Bogor.Bogor. 